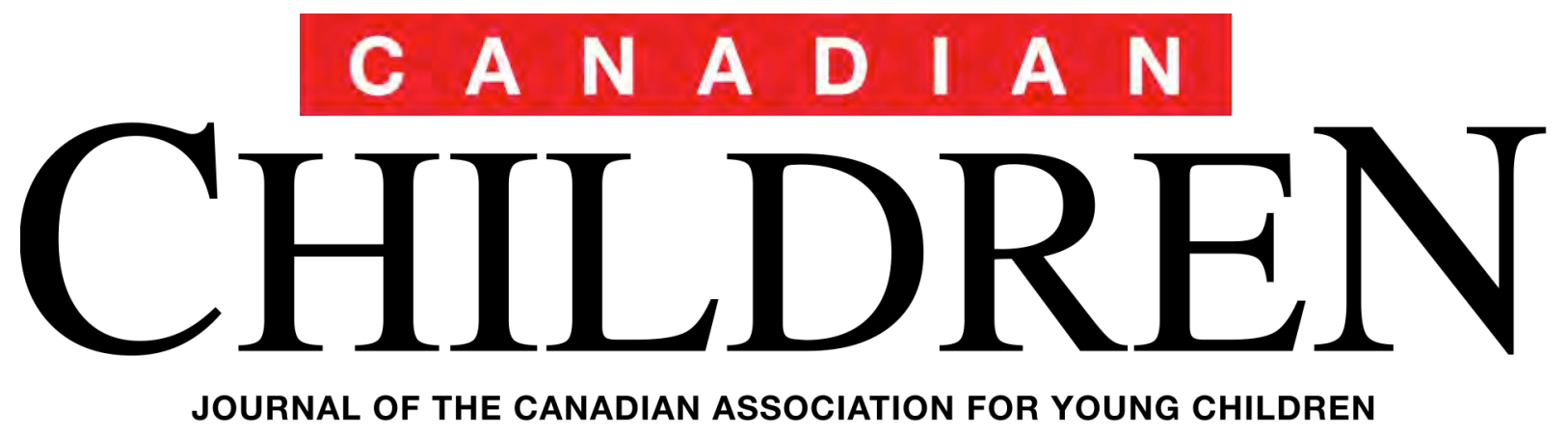

Winter 2014 / Hiver 2014

Vol. 39 No. 1

\title{
Bear-Child Stories
}

in Late Liberal Colonialist Spaces of Childhood

by Veronica Pacini-Ketchabaw, Lara di Tomasso, and Fikile Nxumalo

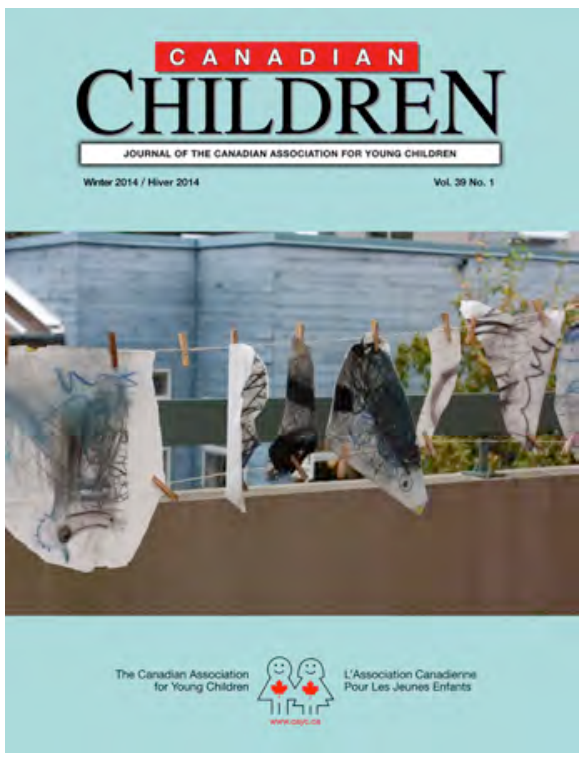

Editors:

Dr. Laurie Kocher, Douglas College, Coquitlam, British Columbia Dr. Veronica Pacini-Ketchabaw, University of Victoria, Victoria,

British Columbia

Guest Editor, Special Issue: Neoliberalism

Dr. Luigi Iannacci, Trent University, Peterborough, Ontario

Publications Chairperson:

Dr. Iris Berger, University of British Columbia, Vancouver, British Columbia

Cover Photo:

Dr. Sylvia Kind

(C) 1996: The Canadian Association for Young Children ISSN: 0833-7519

Author Guidelines: visit www.cayc.ca 


\title{
Canadian Children
}

JOURNAL OF THE CANADIAN ASSOCIATION FOR YOUNG CHILDREN

Volume 39 Number 12014 [page 25 to 53]

www.cayc.ca

\section{Bear-Child Stories \\ in Late Liberal Colonialist Spaces of Childhood}

\author{
by Veronica Pacini-Ketchabaw, Lara di Tomasso, and Fikile Nxumalo
}

\begin{abstract}
Authors
Veronica Pacini-Ketchabaw is professor of early childhood studies in the School of Child and Youth Care, University of Victoria, where she is also the coordinator of the early years specialization. She currently holds a Social Sciences and Humanities Research Council (SSHRC) grant for her ethnographic study "Encounters with Materials in Early Childhood Education," and works in collaboration with members of the Common Worlds Childhoods and Pedagogies Research Collective. Her current research revolves around the pedagogical possibilities of multispecies relations for early childhood.

Fikile Nxumalo is a Ph.D. candidate in the School of Child and Youth Care at the University of Victoria. She currently holds a doctoral SSHRC (Social Sciences and Humanities Research Council) fellowship for her research, which brings posthumanist theories, Indigenous relationalities and postcolonial perspectives into conversation with a focus on possibilities for anticolonial and antiracist responses to everyday encounters in early childhood spaces. Fikile is currently working as a pedagogical facilitator, supporting early childhood educators in her local community.

Lara di Tomasso received a BA in Political Science from McGill University in 2003, and completed her Master's in Child and Youth Care at the University of Victoria in 2012. Her research interests include processes of racialization, ongoing colonialisms, migration, and the ways in which these forces impact the lives of children and families in Canada. Lara currently resides in Toronto, and works as a consultant in the non-profit sector, and as a course writer for the University of Victoria.
\end{abstract}




\begin{abstract}
The article examines the entangled constitution of the child-bear figure through the analytics of late liberal colonial investments. It maps three frictional child-bear encounters, both imaginary and real, in the context of early childhood classrooms: bears as unwelcome and (yet) original inhabitants that pose a threat to human safety, bears as endangered victims in need of human protection, and bears as cuddly and cute creatures in children's literature. Specifically, we explore bear-child entanglements in early childhood classrooms in British Columbia by grappling with the complexities and tensions that emerge in late liberal colonized and colonialist spaces where bears and human children "meet."
\end{abstract}

\title{
Preface: Bear-child Encounters
}

\section{Bears in the Forest}

We often go for walks to the forest close to the child care center. When we encounter holes, both tree hollows and holes in the soil where trees once stood, the children imagine them as 'bear holes': "This is where the bears would take a bath," they chant.
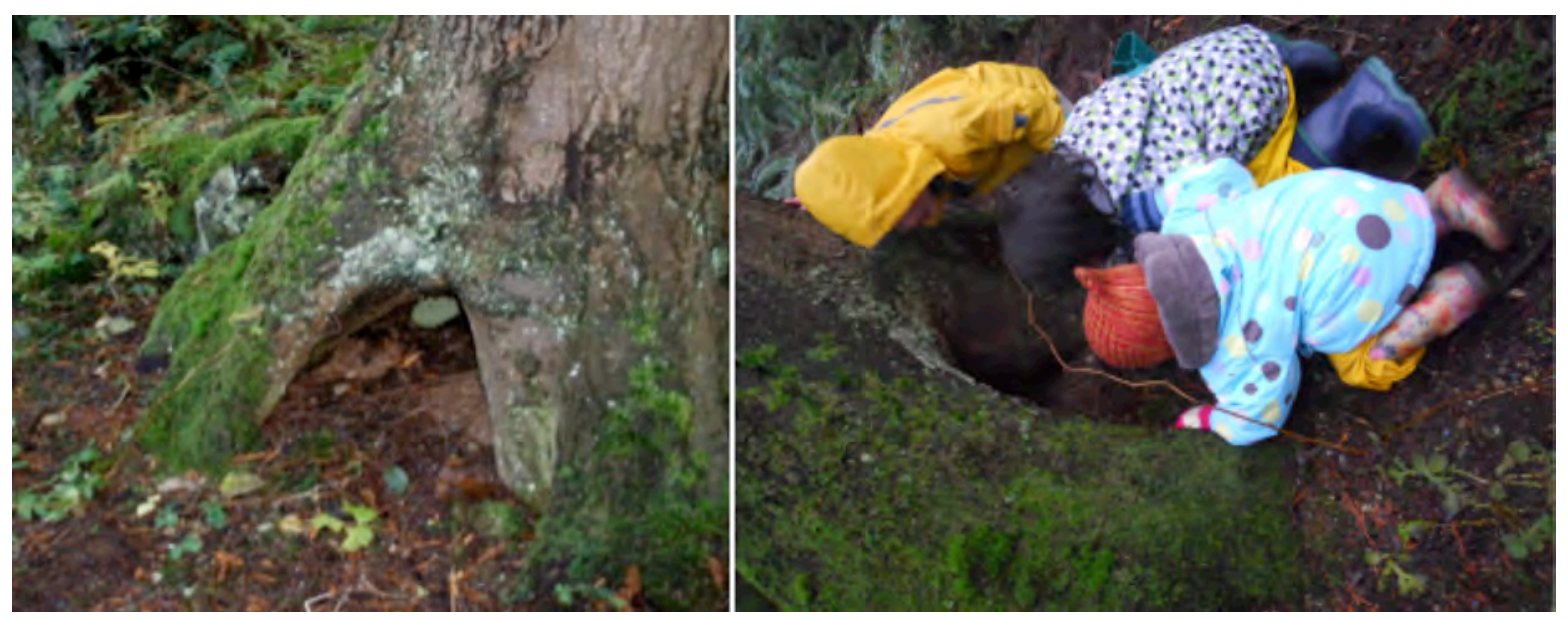

Figures $1 \& 2$

\section{Bear Scenes}

A plastic bear has been placed in a corner of the child care classroom that has been transformed into an 'indoor forest' using sand, tree stumps, rocks, indoor plants and several sticks and branches that the children carry back to the child care centre on their regular walks to the forest. 
A child clutches a stick, stirring the sand and scooping sand onto the bear. "I'm making dinner for the bear", he says. The educator quickly asks, "What is he eating?" The child immediately replies, "The bear is having pancakes--my grandma makes pancakes".

Another child carefully arranges pinecones sticks and rocks in the 'indoor forest' play area while he says, "This is a dark, dark cave. I have made a dark cave for the bear to sleep in. He is going to hibernate for a long time"

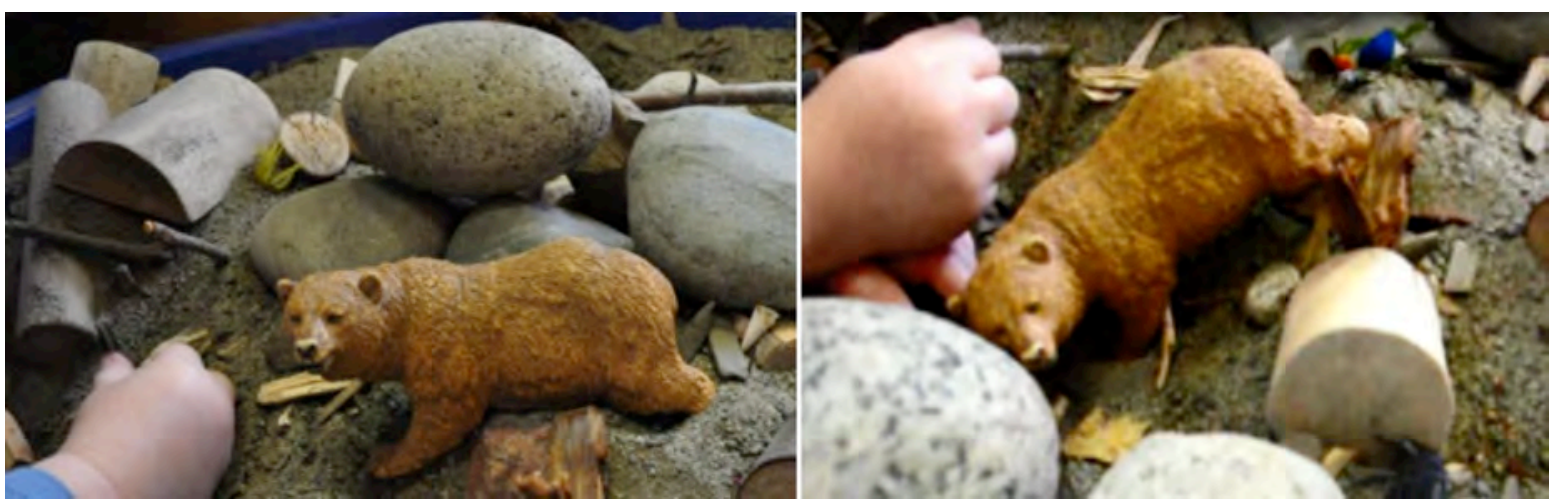

Figures $3 \& 4$

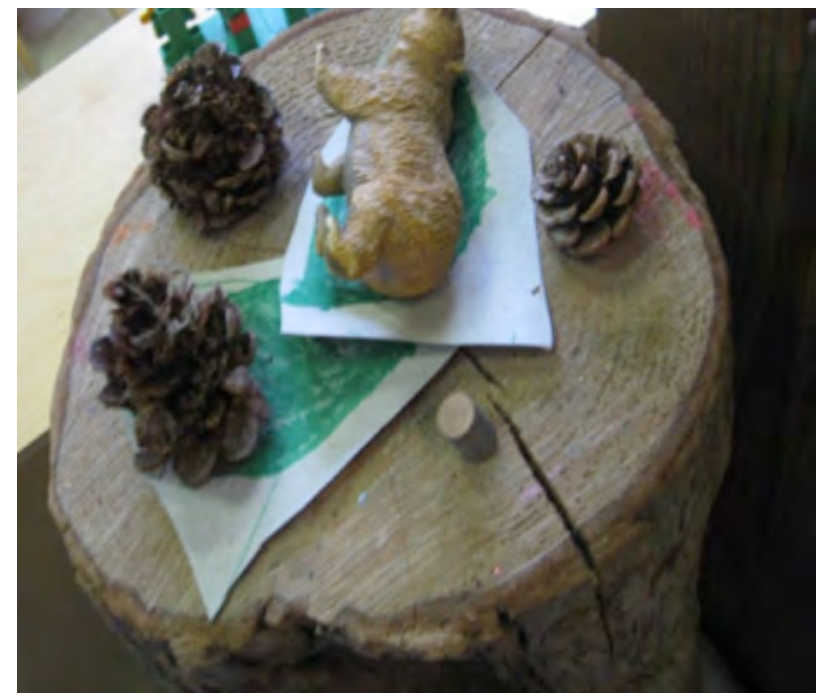

Figure 5 


\section{Bear Paintings}

The children are painting on a large piece of white paper onto which a forest and water image by Coast Salish artist Lawrence Paul Yuxweluptun has been projected. Multiple dialogues emerge. One child says as he paints, "A bear is coming to eat me up"

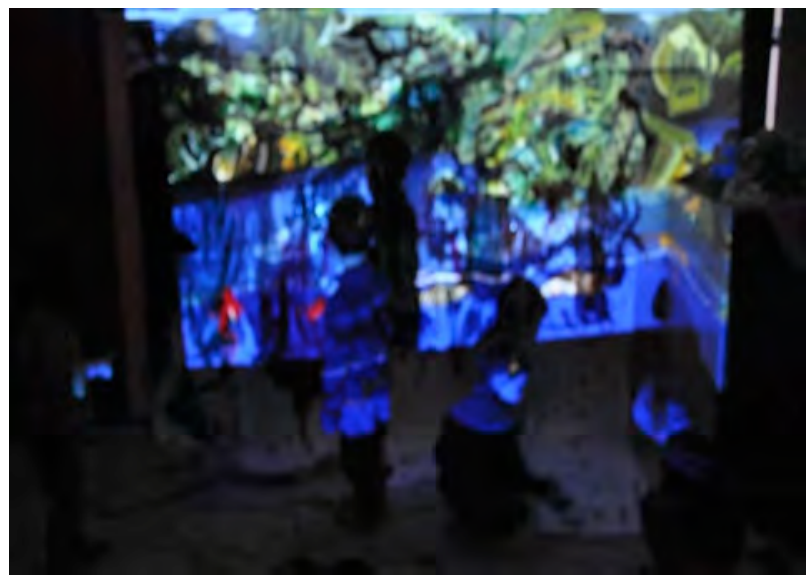

Figure 6

\section{Dangerous Bears}

The children are getting ready to go for their forest walk. Today a group of younger children who have not been at this particular forest before are joining the older group. The older children tell the younger ones what they might see in the forest: "There might be some bears in the forest. But don't worry, we have never seen them before." "It is dangerous. You should be careful..."

It's summertime. The children are on a walk to the forest to pick salmon berries. Leslie, the educator, asks the children to make lots of noise in the forest. When children ask why, the educator explains that they have to let bears know it is their turn to pick berries. Leslie says, "Bears look cute in books, but they are strong and can be dangerous, so we have to make loud noises to warn them. Bears have a different language, we have to talk to them with a big sound to let them know that we are coming to take some berries too". With interest, a child asks, "Why are bears here? Another child adds, "Why are they eating our berries?" Leslie replies, "This is the bears' home. We are visiting the bears' home, the mountain forest. Maybe bears also like sweet berries just like you”. A child responds: "Bears eat honey”. 


\section{Bear Aware}

Following this conversation, back at the child care centre children began drawing or painting pictures of bears eating berries. Leslie brings a bear awareness poster, which hangs on the classroom wall. Over the summer there are a number of bear sightings close to the child care centre that are widely reported in the local media. Leslie and the children continue their conversations about bear awareness.
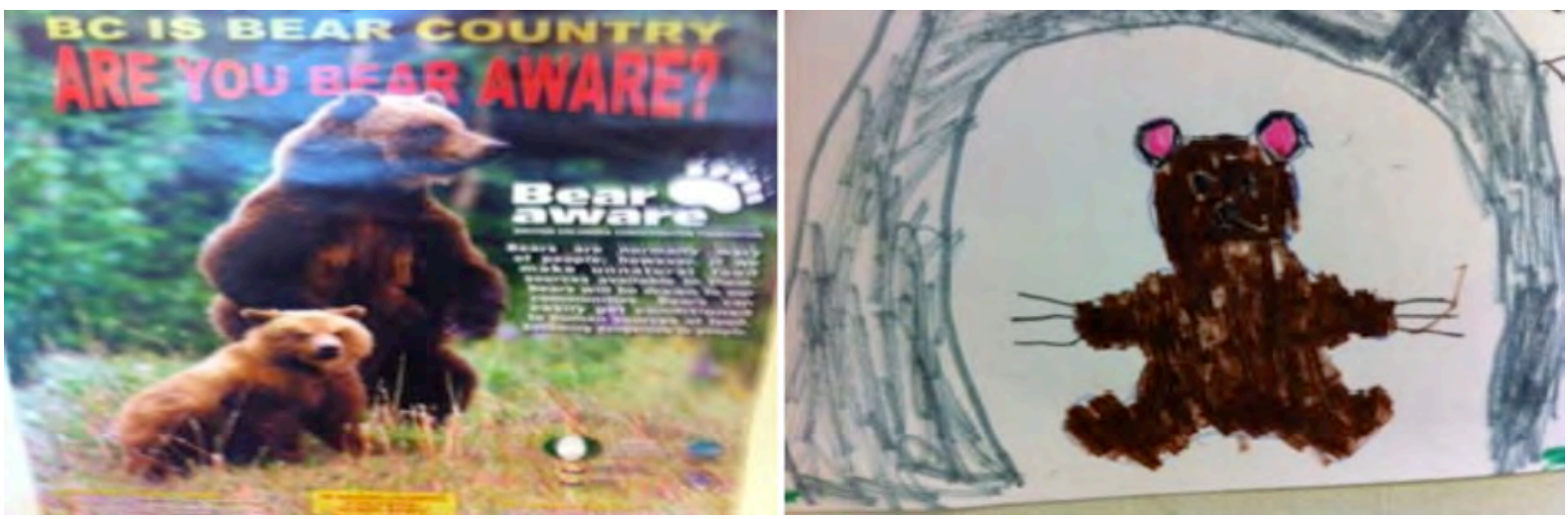

Figures $7 \& 8$

\section{Introduction}

Bears and humans share a long history in the mountains, valleys, and coastal regions of what is now referred to as British Columbia (BC). Bear-human entanglements are constitutive of, and are constituted by, a complex interplay of forces and figurations in late liberal colonialist spaces (Dempsey, 2010). As the stories above demonstrate, early childhood classrooms are not insulated from these past-present entanglements with bears. What takes place in early childhood classrooms occurs within a specific context or, as anthropologist Elizabeth Povinelli (2013) says, a concrete world.

In this paper, we are interested in the forces and imaginaries that maintain connections between early childhood classrooms and the concrete world of late liberal colonialism (Povinelli, 2011). By late liberalism, Povinelli (2011) refers to "a period that marks the co-emergence of variations of neoliberalisms and cultural recognition" (p. 25). Liberalism, she writes, "has entered a new stage of reflexivity" in which "liberal governmentality" assumes new shape "as it responds to a series of legitimacy crises in the wake of new movements" such as anti-colonialism, decolonization and antiracism (p. 25). 
Like Povinelli, we are interested in the ways in which late liberalism handles different modes of being in settler societies and in how these modes of being are made and remade in early childhood spaces.

An important aspect of late liberal colonialism is that it creates "specific arrangements that extend beyond simple human sociality or human beings" (Povinelli, 2011, p. 7; Povinelli, 2013; de la Cadena, 2010). As Povinelli explains, "a social project is dependent on a host of interlocking concepts, materials, and forces that include human and nonhuman agencies and organisms" (p. 7). We appreciate how feminist philosopher Donna Haraway (2008) also makes this point clear in When Species Meet (2008): "Species interdependence", she says, "is the name of the worlding game on earth" (p. 19). Thus, we explore frictional encounters (Tsing, 2005) with bears, both imaginary and real, in the context of early childhood classrooms.

The paper grapples with the complexities and tensions that emerge in these late liberal colonized and colonialist spaces where bears and human children 'meet' and where contradictory images and figures of child and bear abound. Our interest is in the entanglements (the tangled up stories, the tangled making of beings, the intimate coshapings) that take place between bears and children as well as the effects of these entanglements. Worlds are made as bears and children become entangled. These relational entanglements lead us to ask questions about how we want to live with bears in early childhood classrooms.

The idea for this paper came from everyday encounters in the classrooms that we have had the privilege to be in, collaborate with, and learn from through multiple action research and ethnographic projects since 2006. The goal of these projects has been to work with groups of early childhood educators to shift our perspectives and inspire ethical action in response to everyday pedagogical encounters (for details about the studies see di Tomasso, 2012; Pacini-Ketchabaw et al., forthcoming). In this paper, specifically, we explore data about bear-child entanglements that emerged from these projects. In addition, we employ a wide range of children's literature and various media to extend our ideas.

Early childhood spaces in settler colonial BC provide rich opportunities to explore these entanglements. To begin with, these spaces are sites that occupy 'bear country', as we explain later on in this paper. Early childhood classrooms also utilize stories featuring infantilized and human-like representations of bears, as well as bear figurines and toys. As Dempsey (2010) writes, bears have an "extremely cuddly charisma with a face and fur that trigger human concern" (p. 1149), so children are rendered "owners" of toy bears and exposed to a wide range of literature and media that portray bears as friendly creatures. Contradictorily, early childhood spaces in BC also protect children from potentially dangerous encounters with bears. Bears are conjured as fearsome predators and children are seen as particularly at risk from bears - they are considered vulnerable prey in one sense - 
especially during visits to nearby forests as the stories above illustrate. And to make things even more complex, 'bear protection and conservation' activities are often deployed in early childhood sites as a way to develop young children's environmental stewardship and prevent the eradication of bears.

Working theoretically and methodologically with the bear-child figure (Haraway, 1997), and the frictions that this figure brings, this paper offers a multi-layered storying of bear-human and bear-child entanglements. Specifically, it addresses what the figure of the bear-child is becoming within late liberal settler colonialist spaces such as BC (Povinelli, 2011), presents how practices in early childhood classrooms are implicated in the becoming of the bear-child figure, and discusses the responsibilities and obligations that emerge through this becoming. First, we turn to how we use the concepts of 'figures' and 'storying'.

\section{Storying and Figurations in Late Liberal Colonial Times}

We think of the conditions of late liberal colonialism through the figuration of bearchild/human entanglements. If we consider that understandings of the workings of late liberal colonialism require attention to both human and non-human actors, effects and socialities (Povinelli, 2011), then the relations between humans and non-humans are an important way to engage with the effects of late liberalism and its intimate connections to colonial "accumulation by dispossession" (Povinelli, 2011, p. 18). We use practices of storying to attend to, to create disruptions in, and to question how the bear-human figure emerges in current conditions: How does the bear figure become and endure in late liberal colonialism in the context of BC? How does the bear become entangled with children's real and imaginary situated encounters in connection with late liberalism? What kinds of conditions for life are distributed within late liberalism, including modes of recognition, and in settler colonial spaces such as early childhood classrooms? What are the particular modes in which formations of power within this period are organized? What are the figures that organize formations of power in our present times in early childhood classrooms? Storying situated bear-human encounters and entanglements in BC holds potential for generating alternate perspectives that make visible the worldings created by late liberalism in early childhood spaces. As Cameron (2010) explains, stories, practices of storying, and the human and more than human relations that comprise stories create effects. How might stories that attend closely to bear-human relations interrupt "stories of a unified and successful regime” of late liberal governance (Tsing, 2005, p. 271)?

Our intent then, in highlighting particular stories is also to inhabit the frictions and tensions (Tsing, 2005) that these stories bring. As Haraway (1995) notes, "stories do not reveal secrets by heroes pursuing luminous objects across and through the plot matrix of the 
world" (p. 71); instead, they put "unexpected partners and irreducible details into a frayed, porous carrier bag', (p. 71). In other words, these stories build worlds. Taylor, Blaise and Giugni (2012) also use Haraway's approach to storytelling in early childhood education. They explain that Haraway's stories become "collections of ordinary everyday encounters between these 'unexpected partners' -- human and non-human" (p. 2). It is these more than human concerns and their threads and connections that we story here through the bear-child figure.

There are many stories that we could tell. We are leaving out other (equally important) stories. For instance, we do not include here Indigenous bear ontologies; although we write this paper on unceded Coast Salish territories. What now constitutes the majority of BC's territory rests on unceded First Nations land. The research projects and early childhood practice settings from which we generate the stories used in this article are located on land belonging to the K'ómoks, Qualicum, Snuneymuxw, Quw'utsun, Esquimalt, Squamish, Songhees, Saanich, Musqueam, Tsleil-Waututh, Kwikwetlem, Stó:lô and Semiahmoo First Nations (British Columbia Assembly of First Nations (BCAFN), 2012). In what is now referred to as BC, there are over 200 distinct First Nations (BCAFN, 2012), speaking 32 different languages (First Peoples' Heritage, Language and Culture Council, 2012). Yet, these rich geontologies (Povinelli, 2013) are silenced and ghosted through ongoing colonialist practices and policies.

We have chosen to not tell Indigenous stories in this short paper as they deserve much more than just a brief mention. Byrd (2011), Cameron (2008; 2011) and Povinelli (2011) also remind us that settler colonial ghosting persists in 'well-intentioned' research that perpetuates colonialisms by re-centering and re-inscribing settler perspectives through the relegation of Indigenous peoples to the past or to a "spectral presence" (Povinelli, 2011, p. 39) and by taken for granted appropriations of Indigenous knowledges. As Byrd (2011) notes, anticolonial articulations risk perpetuating colonial "discourses of indigenous displacements that remain within the present everydayness of settler colonialism, even if its constellations have been naturalized by hegemony and even as its oppressive logics are expanded to contain more and more historical experiences" (p. xviii).

We focus on the bear figure in settler-society, both historical and contemporary, so as to explore the means by which 'bears' derive their power as figures in relation to childhoods in the specificities of the colonized, late liberal spaces that we inhabit. The stories we tell from our research are unavoidably entangled with settler colonial relations, not only in the kinds of stories we tell but also in how we tell our stories, in our ways of relating to these stories, and in the bear-child entanglements themselves.

We story bears and bear-child entanglements as "a Harawayian figure", as Collard (2012) calls them. This figure is "both metaphorical and real" (Collard, 2012, p. 524) and helps us to query particular knowledges, power asymmetries, practices and relations 
(Haraway 1997) that connect to late liberalism, including their colonialist troubles and implications. We work with figures and not agents per se. We are interested in how bears come to work as a figure for the kinds of problems that we grapple with; with the hope that with and through these figures we can capacitate new forms of social imaginaries. That is to say, we are interested in working with the bear figure and its accompanying performativities, as "maps of contestable worlds" (Haraway, 1997, p. 11) not only to make visible and unpack the situated workings, tensions, complex power relations, and effects of late liberal settler colonialisms, but also to produce "some kind of displacement that can trouble [the] identifications and certainties"' (Haraway 1997, p. 11) that accompany these forces of late liberalism. In other words, as Timeto (2011) notes, figures "do not simply figure, but 'turn' what they figure” (p. 161).

In previous work, we have examined the workings of late liberalism in early childhood education as uneven and as "a set of dispersed stances" (Povinelli, 2012, n.p.) comprising shifting heterogeneous material-semiotic, human-non-human linkages, and multitudinous effects that are not necessarily easily pinned down (Nxumalo, PaciniKetchabaw \& Rowan, 2011; Pacini-Ketchabaw, Nxumalo \& Rowan, in press). Social projects such as late liberalism and neoliberalism, Povinelli (2011) writes, are not uniform, homogenous formations of power or even "terrains of social maneuver" (Povinelli, 2011, p. 28). Consequently, we see inhabiting the mobile 'more-than-representational' bear figure as a useful way to engage with the complexities of late liberalism and its shifting and contradictory techniques of governance and surveillance through "recognition-espionagecamouflage" (Povinelli, 2011, p. 30). In other words, the bear figure allows us to map, through practices of storying, situated intricacies of late liberal settler colonial worldings, including the "stakes, alliances, and action of a much-enhanced array of constituents and producers of what may count as fact" (Haraway, 1997, p.270). Through our stories, we inquire into how bears become in late liberalism both "creatures of imagined possibility and creatures of fierce and ordinary reality" (Haraway, 2008, p. 5), and how these figurations come to matter as late liberal settler colonial worldings in everyday bear-child encounters. Exploring how figures come to matter permits us to ask: What "otherwise" stories might be told of our relating to bears that disrupt the story written through late liberal colonial imaginaries? How might we negotiate this slippery reworking of stories in ways that do not romanticize and appropriate bear-child relations?

\section{Multi-Layered Stories of Bear-human and Bear-child Entanglements}

In this section we trace human/bear entanglements across time and space in North America, but we pay close attention to the territories now referred to as BC. We consider bears both as the animals that have roamed across North America for millennia, and as the various bear figures that are brought into being through entanglements with humans. These 
entanglements have never, and do not, occur in neutral space; rather they are layered upon diverse histories and play out in varied presents, all of which are tied to processes of colonization, continued colonialisms, and the topographies carved by late liberalism. We begin by presenting the figure of the bear in $\mathrm{BC}$, and follow by briefly tracing stories of bear-human entanglements as colonialist efforts in late liberal times. Then, we introduce stories of how bear-human encounters are making headlines in $\mathrm{BC}$, and turn to stories that describe bears as dangerous animals and stories that situate bears in 'bear country'. Stories of bear commodification and stories of the management and control of bear-human encounters are also addressed. All of these stories are layered upon stories from early childhood classrooms and children's literature as well as news media to trace threads of bear-child entanglements.

First though, we have a few words of caution for the reader. Storying through a Harawayian figure does not mean that we tell stories in a logical manner or that we make orderly and tidy inferences that could neatly fit in a box. We do not engage with the stories presented here in order to arrive at the 'truth'. Our goal instead is to pull and tangle threads by constantly linking stories to see what they do together. We are interested in entanglements. Our stories are entangled, not neatly packaged together, without following a linear trajectory. The stories aggregate; they add up to create other stories and to disrupt taken for granted stories. They are stories that grapple with troubles, with connections that trouble us, but have no generalized moral teachings nor are they finished stories of grandiose research findings. They do, however, have "consequences for response-ability" (Haraway, 2012, p. 312), which we will address in the last section of this paper.

\section{Bears in British Columbia}

British Columbia is home to the Grizzly and the Black bear. It is estimated that 18,000 years ago, Black bears lived in two temperate refugia on the continent, and are believed to have spread out over North America following glacial melting at the end of the last ice age (Government of British Columbia, 2001). Encounters with Black bears, who are far more numerous than Grizzlies, are the most common type of bear-human meeting in BC. In 2001, the Black bear population in BC was estimated between 120,000 and 160,000, which accounted for approximately $25 \%$ of the Black bear population in Canada (Government of British Columbia, 2001). Depending on the climate, Black bears will hibernate for several months during the year, with bears in the interior and the North of the province hibernating for up to 7 months per year (Government of British Columbia, 2001). Black bear cubs are born during hibernation, and weigh only half a kilogram or less at birth. Female Black bears are solely responsible for raising their cubs, and nurse them for quite some time. As more and more Black bears become accustomed to having access to a year round supply of garbage, hibernation patterns seem to be changing, with some bears not going into 
hibernation at all (Government of British Columbia, 2001).

Bears require large amounts of food, and have diverse diets depending on the season and the context in which they find themselves. In their natural habitats, bears eat small and large mammals, berries, salmon, fruit, nuts, and vegetable matter (Government of British Columbia, 2001). They are opportunistic eaters (Dempsey, 2010) that seek out high-energy foods that do not necessitate the expenditure of high amounts of energy to access (Government of British Columbia, 2001), which is why they find human garbage so attractive. Bears play a vital role in larger eco-systems, particularly through their eating habits. For instance, "the transport of seeds via bear droppings aids the dispersal of many species of berry-producing shrubs. Along salmon spawning streams, bear feces and the remains of fish carried into the woods contribute to the long-term nutrient cycle in oldgrowth forest" (Government of British Columbia, 2001, p. 4).

The Spirit, or Kermode bear, is found in the temperate rainforests along the Pacific coast of BC, and is a subspecies of the Black bear. The Spirit bear most often has a white or cream-colored coat due to a recessive gene mutation that is passed down by both parents. The name Spirit Bear is thought to possibly come from a First Nations name, however the Tsimshian people refer to it today as "moskgm'ol" or "white bear" (First Nations Drum website, 2012). The Kitasoo/Xaixais people believe that these bears are a remnant and reminder of the last ice age (First Nations Drum website, 2012, par. 3). Local First Nations never hunted white bears, and managed to keep their existence hidden from settlers and traders throughout the BC fur trade (Barcott, 2011).

As we noted in the introduction, bears are not imaginary, distant creatures to children in BC. This is evident in the stories we included in the preface. But there are also plenty of opportunities for children to learn about bears and bear facts through literature. The literature though is very diverse. Cute bears abound in children's storybooks (Coats, 2013). As Coats (2013) writes, "The ubiquitous rise of the teddy since 1903 has given the cuddly sort of bear a firm place in most modern children's hearts... There are sleepless bears, scary bears, wise old bears, magical bears, sad bears and spaceman bears..." (par. 1). In fact, these are probably the kinds of stories that might resonate the most with children, educators and families. Yet, these stories are far removed from the bears that live in BC. The kinds of narratives deployed in these books work to distance children from the relations that sustain humans and other species on this land-and we expand on this below.

The real-life bears that children in BC might encounter are depicted in stories such as $S$ is for Spirit Bear: A British Columbia Alphabet" (2006), written by Roberts and illustrated by Doucet. This book entices different kinds of relationships with bears than the children's storybooks described by Coats (2013). S is for Spirit Bear, distributed to all kindergarten children in the province, makes interesting and particular connections between the "natural" world and children's worlds. It also suggests/presents non-human others in 
what is now considered $\mathrm{BC}$ as distinctly $\mathrm{BC}$, as "belonging" to the province and thus doing important work to construct and deploy ideas about $\mathrm{BC}$ as 'the most beautiful place on earth'. These kinds of narratives are not innocent in that they have become a late liberal colonial campaign to sell the province's non-human others as tourist attractions. The protection of bears as resources for tourism is the primary message in $S$ is for Spirit Bear. Bears need to be protected because they provide a return. The attachment between children and bear here is created through the idea of 'loving pristine nature' and 'saving the planet'. Interestingly, while children are intentionally exposed to these messages, the province continues to expand the fast growing extraction of minerals from the land. Ironically, the profits from mineral extraction go towards funding the production of $S$ is for Spirit Bear and the overall provincial (although lacking) early childhood system.

We begin to see here the types of frictional and messy bear-child entanglements that constitute the focus of this paper. The complex narratives in these children's books are part of, as Povinelli (2011) says, late liberal colonialism and they are deployed through "aggregating practices, incessantly fixing phenomena and consubstantiating practices" (p. 8). Within late liberalism, as with any other social imaginary, certain forms of life are made (become) possible. Yet, as Povinelli (2013) explains, every form of emergence (every new possibility) is coupled with a form of extinguishment. Although a liberal imaginary might (mis)lead us to think that we can pluralize everything infinitely, or simply 'make room' for new forms of life, what is always at stake in this social imaginary is life itself - something (another way or form of life) has to be extinguished. In other words, the cost of something emerging is the extinguishment of something else.

\section{Bear-Human Entanglements and Colonial Ties}

The frictional bear-human entanglements we are beginning to thread can be traced historically through the colonization, theft and settlement of land in North America. Dempsey (2010) emphasizes that settlers' accounts and records of expeditions in the West highlight numerous instances of human encounters with Grizzlies. Historically, bears feeding on the cattle and sheep of settlers were killed, and this eventually resulted in their wholesale extermination over large parts of North America (Dempsey, 2010). Describing the Grizzly bear's dangerous interface with the colonizer's mission, Dempsey (2010) writes: "Grizzly bears posed specific economic threats, but were also considered more generally as 'dangerous impediments to progress' by colonial settlers, undoubtedly influencing the pace of killing and 'civilizing' of the landscape" (p. 1143).

Colonization and the emergence of capitalist markets thrust bears into the heart of biopolitical concerns, whereupon their survival was calculated according to the cold science of economics and the necropolitics (Mbembe, 2001) of colonization. This calculated 
swapping of life - the extinguishment of one form of life for the emergence of another (Povinelli, 2011) - grew out of the violence of colonization, and continues today through the neo-colonialist processes inherent to late liberalism that shape bear-human entanglements in $\mathrm{BC}$.

There were other concerns and forces at play in bear-human entanglements after the arrival of European settlers than the safety of livestock. Dempsey (2010) asserts, “... while the eradication of bears was impelled by economic rationales, it was also a part of a project of producing 'biosecurity"' (p. 1144), which facilitated the understanding and description of practices whose primary goal was/is to make human life safe (Collard, 2012). The threat (real or imagined) of large predators to human life justifies protective measures through, as Bingham (2008) explains, the regulation, monitoring, and halting of movements of certain bodies. As we will explore through the news story below about a recent bear attack in BC, bears who attack humans are often rendered "killable" through the way in which they "[unmake] safe space" (Collard, 2012, p. 35).

As European settlers scrambled westwards across what is now referred to as Canada, an imagined country began to take shape. The West Coast was the last region in southern Canada to be colonized, and images and stories of pure, untamed wilderness and 'real' Natives soon fed the national imaginary. Bears became part of this imaginary. Braun (2002) explains that by the 1880 s, the West Coast of Canada had been produced as a distinct region in the Canadian national imaginary and bourgeois travelers flocked to the Inside Passage (a route followed by boats that weaves between the islands of the Pacific northwest and the mainland). Braun (2002) writes:

From the comfort of the ship deck one could view nature - and Natives - as a passing spectacle. The effect of such distancing was to evacuate specific meanings assigned to places and incorporate them instead into a mythological space that had little to do with the lived details of particular sites and much more to do with discourses of European modernity and national history. (p. 220)

This is still the case today in terms of ecotourism, which relies heavily on wildlife viewing tours. Customers pay for the ability to gaze upon bears, wolves and whales in their natural habitats from the decks of boats along the coast of $\mathrm{BC}$; an experience completely devoid of the traces of the contested and bloody entanglements that humans and bears have been embroiled in for the past 150 plus years.

Perhaps an example that still carries the image of the bear devoid of colonial struggles, depicts nature as pure and innocent, and presents the notion of trouble-free childhood separated from big predators, is one that many children encounter today in Winnie the Pooh (1926) written by British author A. A. Milne. There are many excellent analyses of the story itself (for examples see Hemmings, 2007; Kutzer, 2000). What interests us for 
the purpose of this paper are the links between the story and an actual bear. The story goes something like this. Winnie the Pooh was, in part, named after the toy bear Winnie that belonged to Milne's son Christopher. Christopher had named his toy bear after a Canadian Black bear (originally called Winnipeg) that he had fallen in love with through his regular visits to the London Zoo where Winnie was kept. The Historica Foundation of Canada describes the colonial links of this 'lovable bear':

Winnipeg emigrated to Britain along with her owner, Captain Harry Colebourn, an army veterinary surgeon in the Canadian military. In 1915, as World War I raged, Captain Colebourn was sent to the front in France. Unable to take Winnipeg along, he donated her to the London Zoo, where she quickly became a star attraction.

Colebourn purchased Winnipeg in White River, Ontario from a trapper who had killed the cub's mother. She was named after Colebourn's hometown. (Winnie, 2008, par. 34)

Through Winnie the Pooh, we thus find traces of British imperialism, the colonization of Canada, and the subordination of the Black bear to the whims and viewing pleasure of European settlers. This is not to say that a child who encounters Winnie the Pooh understands these complex forces, however the figure of the bear conjured in this story carries with it a history that still bears traces of the colonialist, imperialist dynamics that brought the story into being.

\section{Bears in the News}

While bear-human entanglements stretch back thousands of years, actual encounters between bears and humans in BC are increasingly common as cities, suburbs, agriculture and industry sprawl outwards into bears' natural habitats. Forestry and mining industries cut into larger and larger swaths of the landscape, while more humans venture into the wilderness as part of the province's burgeoning eco-tourism industry. For example, the government of BC advertises the province as 'the most beautiful place on earth'. Yet, these narratives of unspoiled wilderness work to serve the ongoing colonial project (Braun, 2002) as what seems to be 'pure' untouched areas were often created by depopulation through colonial practices (Povinelli, 2012); meanwhile urban and industrial encroachment into bears' habitats continue. Bear-human entanglements can be peaceful, but are increasingly bloody. Here, we turn to the nature of some of these entanglements, and what is produced through them. 
As we write this paper, several bear attacks in $\mathrm{BC}$ are in the news. Bear-human encounters in $\mathrm{BC}$ are not uncommon, and the media diligently covers the bear-human conflicts in which bears are the perpetrators of an attack. One of the most recent incidents was covered by an article appearing July $5^{\text {th }}, 2013$ on the Canadian Broadcasting Corporation (CBC) website: "Grizzly bear attack of BC men brings terror and screams". Two men in the Kootenay region of the province who were scouting for a deer hunt inadvertently found themselves between a mother bear and her cub. The men recount that with no warning, the bear attacked, swatting at them and swinging one man through the air and down a hill. The bear spray that one man used was ineffective. "The most terrifying part was I was so vulnerable, head down hill, feet up. I was screaming. Her face was no more than a foot from my boot. And she turned around and left" (CBC, 2013, par. 11). In accordance with law in provincial parks, the rifle that one of the men was carrying was unloaded at the time of the attack. Officers at the scene asserted that the men did everything right, and that this was just a case of being in the wrong place at the wrong time. The bear in this encounter was also deemed "not to blame" as this type of behavior is considered normal when a bear is caught off guard by the presence of humans; particularly when a human comes between a mother and its cub.

Mother bear stories are not uncommon in early childhood education. In the following dialogue two educators during one of our research focus groups (PaciniKetchabaw et al., forthcoming), discuss how they feel about protecting a child who was excluded from 'princess play' because her skin is brown.

Miriam: But then that brings up for me ... I am really protective of that little girl. For me, I don't want her to be the subject of a big, intense conversation about why she's different. I, you know, I've got that ferocity ... of protection... I get that really ferocious.

Gaile: Mother bear.

Miriam: Mother bear! Absolutely.

Gaile: Oh ya. [Laughing]

Miriam: Absolutely. So I - I wanted to protect that little girl. I don't want anybody to be making her uncomfortable with herself.

Gaile: Mmm hmm.

Miriam: So, I'd love to talk about it. But I'm afraid to, because I don't know ... if I can protect her, or how I would protect her. 
In the above excerpt, the mother-bear figure is used to respond to a racialized encounter in the classroom. We have thought about the complexities of this story in other publications (di Tomasso, 2012; Pacini-Ketchabaw et al., forthcoming). Here we highlight the geo-historical circumstances of this event. We are reminded that this dialogue, as well as the encounter that is discussed, take place in colonized space, stolen-unceded land, as well as in bear country/habitat. Appropriation and displacement take place on different levels simultaneously, and we wonder: Who has the right to the mother-bear figure in colonized, colonialist space? What kinds of pasts-presents are conjured when non-Indigenous educators and researchers on stolen land (stolen from all Indigenous inhabitants, including bears) invoke the figure of the mother-bear in a move to "protect" a racialized child from the materiality of her own body? And, importantly, what kinds of responses were rendered impossible through the utilization of the mother-bear figure in this context?

Although the "mother-bear" instincts that are often referred to in early childhood settings may be taken as a simple figure of speech, these affective engagements with bears are charged with late liberal colonial narratives, defined through relations of power that bring about displacement and appropriation. As Povinelli (2011) reminds us, late liberal colonialist discourses of protection and recognition may appear to care for 'difference', while also working to keep the other 'in place' without agency or with agency defined by the 'protector'. While "late liberalism is a belated response to the challenge of social difference and the alternative social worlds and projects potentially sheltered there", late liberalism continues colonial violences in that it allows "cultures a space within liberalism without rupturing the core frameworks of liberal justice" (p. 26). Povinelli continues: "In late liberalism to care for difference is to make a space for culture to care for difference without disturbing key ways of figuring experience - ordinary habitual truths" (p. 26). In the case of the dialogue, the mother-bear invocation maintains, as we outlined above, certain bodies situated within the temporalities and spatialities of the settler state.

A second news story that is relevant to our discussion describes a Black bear attack in an urban area. Appearing on the Canadian Television Network (CTV) news website on July 12, 2013, an article entitled "Man nursing scratches after Mission black bear attack" describes a man that was lunged at by a bear on a walking path near several busy streets in the town of Mission, BC. The human involved in this attack was also deemed to have 'done everything right', but in this case, the bear's behavior surpassed what is considered acceptable, normal, or safe. A conservation officer interviewed on video about the attack asserted, "As a result of its behavior and the aggressive type nature, we'll probably have to put this animal down".

These stories are complex renderings of layered dynamics and forces that imbue encounters between bears and humans with particular meanings. The notions in both news articles of appropriate and inappropriate behavior, safety, and protection reveal the ways in 
which humans attempt to manage and police space and the encounters that occur therein between human and non-humans. The intensity and type of attention these media articles generate are indicative of society's fascination with bears, and fear of them. As neighbors and as natural inhabitants of BC's perceived untamed wilderness, bears have a particular hold on imaginaries in settler societies. Bear figures in settler colonial late liberal space are also utilized in specific ways to conjure up particular types of humans: bears used as symbols of unspoiled wilderness are thus considered representative of the province's robust environmental protection laws; bears constructed as victims position humans as their benevolent protectors; and bears as wild, fearsome aggressors construct humans as vulnerable victims in need of protection. These various entanglements between bears and humans produce particular figurations of both bear and human, which are the product of late liberalism, and also inscribe the landscape of late liberalism with the messy, bloody, unfinished traces of these encounters.

\section{Bear Country}

Most of $\mathrm{BC}$ rests on what some environmentalists refer to as 'bear country'. This phrase in and of itself is interesting, as the provincial government, municipalities, industry, businesses, and human residents seem to be embroiled in a continuous battle to delineate and enforce bear-free space. For reasons that we discuss in more depth later on, this has become an increasingly difficult task. Bears populate every corner of the province, and are considered plentiful enough by the government to allow bear hunting licenses in the majority of the province's regions. When one thinks about 'bear country', images such as the photo shown in Figure 9, (taken during one of Lara's hiking trips in Golden, BC, home to both Grizzly and Black bears), may flash before one's eyes: wide open expanses, roaring rivers, towering mountains, and no apparent trace of human development.

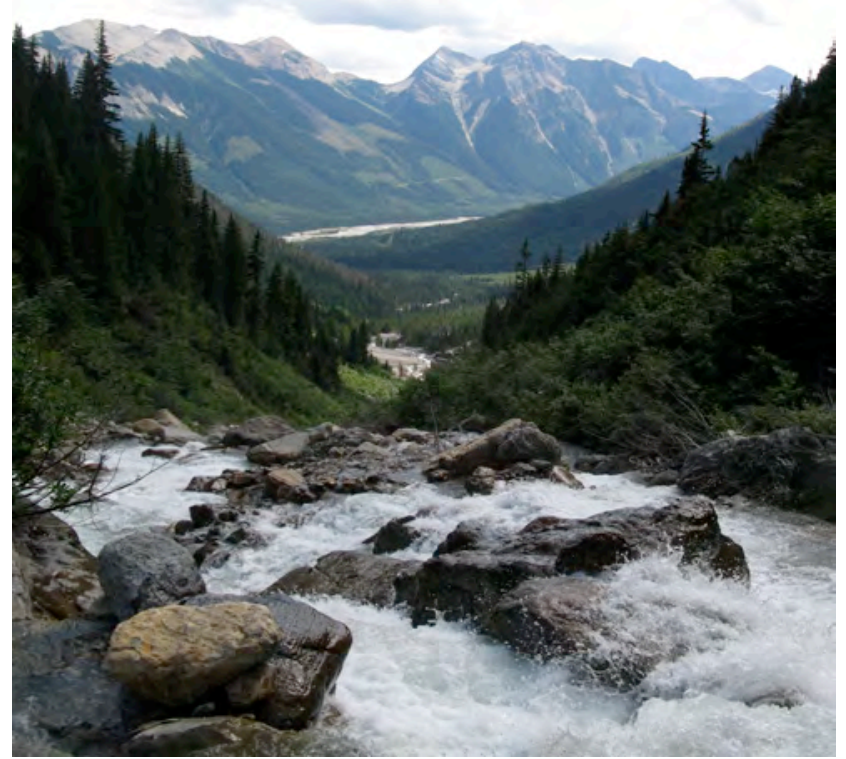

Figure 9 
This image also populates children's imaginations when they explore the forest. In the encounter Bears in the Forest (presented in the preface of this paper), the bear as a creature that roams natural, untouched land devoid of human presence is part of children's imaginaries. Bears become the mysterious creatures that live in places that are outside of children's worlds. Perhaps this is even more salient in Dangerous Bears, where children and the educators are visiting the 'bear home'.

However, 'bear country' looks increasingly like Figure 10 (retrieved from City of Coquitlam, n.d.) below: pavement, street signs, condominiums, manicured lawns, and garbage bins. Are these the worlds that children are 'becoming with' in Bear Scenes (the story introduced in the preface of this paper)? Perhaps there is more to Bear Scenes than just innocent dramatic play or problematic representations of 'real' bears. Might encounters such as Bear Scenes be the spaces where children and bears breathe and "grapple inside the flesh" (Haraway, 2007, p. 4) of the contradictions and tensions of late liberal colonial relations? And, just as important, how do we respond to these contradictions and tensions in early childhood classrooms?

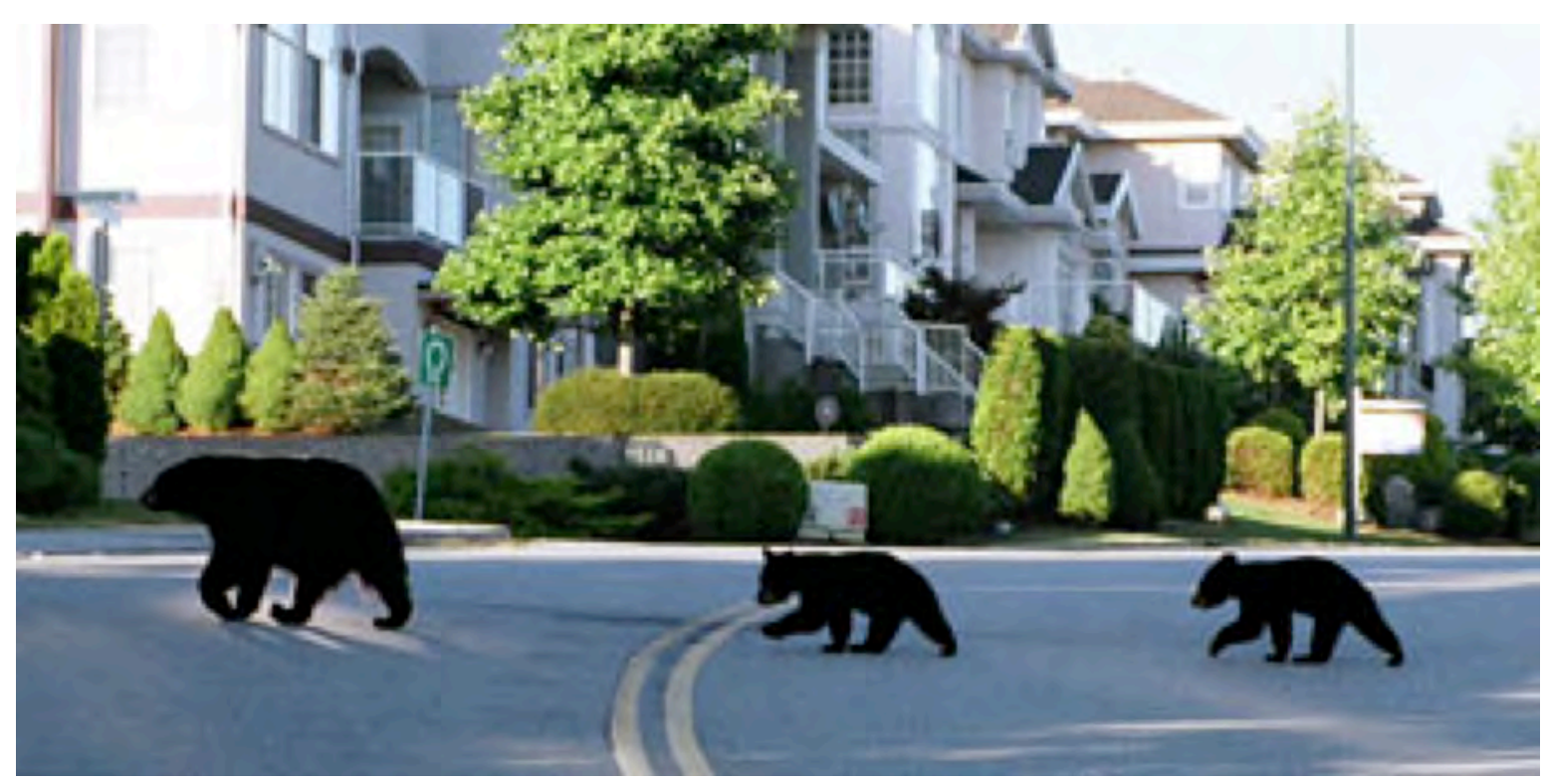

Figure 10

Figures 9 and 10 depict encounters that tell us about the ways in which bears and humans consistently disturb the boundaries between human-space and bear-space that have been arranged through late liberal colonial relations. Borders have been established in an effort to construct safe and appropriate spaces for humans (including human children, as the Bear Aware encounter presented in the preface demonstrates). Often bears pay a much heavier price for transgressing those boundaries than humans do. Going back to Povinelli 
(2013) we can remind ourselves that in late liberal colonial times there are always lives that need to be extinguished in order for other forms of life to flourish. Yet, we are by no means suggesting that we should put children at risk of an encounter with bears. We do want to

point out however that these are the very risky situations of life and death in which we swim in late liberal colonialism.

\section{Bears as Commodities}

We begin here with We're Going on a Bear Hunt (2003) written by Michael Rosen and illustrated by Helen Oxenbury. This is a famous British children's book that tells the story of five children, a baby and a dog going on a bear hunt. Here is how the author describes the book: "The words were designed for a kind of play-song that you act out as you sing it. The book is an insight into a drama being faced by what is actually quite a vulnerable group: five children, a baby and a dog" (Tims, 2012, par. 11). The song goes like this:

We're going on a bear hunt.

We're going to catch a big one.

What a beautiful day!

We're not scared

Uh-uh! Grass!

Long wavy grass.

We can't go over it.

We can't go under it.

Oh no!

We've got to go through it!

Swishy swashy!

Swishy swashy!

Swishy swashy! 
We're going on a bear hunt.

We're going to catch a big one.

What a beautiful day!

We're not scared.

We're going on a bear hunt.

We're going to catch a big one.

What a beautiful day!

We're not scared.

Uh-uh! A forest!

A big dark forest.

We can't go over it.

We can't go under it.

Oh no!

We've got to go through it

Stumble trip!

Stumble trip!

Stumble trip!

WHAT'S THAT?

One shiny wet nose!

Two big furry ears!

Two big googly eyes!

IT'S A BEAR!!!!

Quick! Back through the cave! Tiptoe! Tiptoe! Tiptoe! 
Back through the snowstorm! Hoooo woooo! Hoooo woooo!

Back through the forest! Stumble trip! Stumble trip! Stumble trip!

Back through the mud! Squelch squerch! Squelch squerch!

Back through the river! Splash splosh! Splash splosh! Splash splosh!

Back through the grass! Swishy swashy! Swishy swashy!

Get to our front door.

Open the door.

Up the stairs.

Oh no!

We forgot to shut the door.

Back downstairs.

Shut the door.

Back upstairs

Into the bedroom.

Into bed.

Under the covers.

We're not going on a bear hunt again.

We include this story here because it is one that is rehearsed every time we visit the forest with young children. It is the stories that become invisible and untold in early childhood spaces that we want to turn to as the 'otherwise' story of late liberal colonialism in the classroom. The hunt.

Bear country is contested space, for a multitude of reasons, and bears themselves have become a contested commodity within this space. Take for example a recent disagreement between several First Nations and the provincial government over the bear hunt. The most common, and the most bloody type of encounter between bears and humans in BC occurs as a result of the hunt of bears for sport. The tourism industry and the provincial government reap large profits from the bear hunt. The province sells hunting 
licenses to hunters for trophy kills, and tourism companies sell hunters the promise of killing a bear. A Canadian Broadcasting Corporation (CBC) online article (September 13, 2012) entitled "Bear hunting ban declared by 10 B.C. First Nations, but provincial government says only it has the authority to declare such a ban" provides an example of the contested meanings that circulate within late-liberal, colonialist space. In the article, William Housty of the Heiltsuk First Nation asserts that bear trophy hunting threatens ecotourism opportunities for First Nations and goes against the values of management and cultural beliefs of First Nations people. He states, "Because we have not ceded any of this land to anybody, we feel that we have a voice and should have a voice in how these lands are managed and this includes the bear hunt" (par.7). However, the hunting industry yields $\$ 350$ million in revenues for the province annually (CBC, 2012) and the government is not about to relinquish jurisdictional power in this regard. In the article, BC Minister of Forests, Steve Thomson, states that the hunt is managed on "sound science" and is sustainable. Instructively, Metcalf (2008) explains:

Much contemporary North-American environmentalist and anti-environmentalist discourse relies on bears as a trope for human-wilderness relations, both to the betterment and detriment of actual bear populations. The stories we tell of bears can be both data and normatively compelling. But this use of bears as a model or trope for human experience is nothing new; it has unexpected echoes throughout the mythologies and materialities that inform our storytelling practices.

One of the ways in which bears are presently figured as threats to late liberal capitalism is through their parallel figuration as a synecdoche for entire conservation regions (Dempsey, 2010). Dempsey (2010) explains that environmental campaigns to protect particular areas have used the cultural and discursive importance of bears, as well as their material needs for water, food and land, as arguments for increased environmental conservation and protection. Therefore, we can also see the use of bears as a form of currency in battles waged between governments, industry, and environmental groups. This was especially true of the so-called "Great Bear Rainforest" conservation initiative, concerned with the temperate rainforest that stretches up the length of BC's coast. Bears are still used as symbols of the rainforest and the advocacy organizations that have sprung up to protect this massive area.

An example of bears used as symbols is the upcoming move to advertise the storybook Spirit Bear (2013), written by Jennifer Harrington and illustrated by Michael Arnott, as an 'eco-book' (the story and illustrations are available on the publisher's 
website). The publisher, who specializes in books that promote children's love for reading and environmental conservation, describes the purpose of the book as follows:

Spirit Bear is an entertaining, educational book intended to raise awareness about the spirit bears of British Columbia, whose habitat is currently under threat by the proposed Northern Gateway and Trans-Mountain oil pipelines. This book has been researched in order to make it as biologically accurate as possible, so that teachers may use it in their biology curriculum. The book will be accompanied by free resource materials for educators to make it easy for them to implement Spirit Bear into their lesson plans. Spirit Bear will be available as an ebook, and as a paperback printed on $100 \%$ recycled paper with an FSC cover. (par. 2-3)

As the discussion up to this point elucidates, bears are incredibly powerful symbols that conjure up particular realities and imaginaries. They teeter on a fine line in lateliberalism - the line between their figuration as profitable, exploitable commodities, and/or their figuration as threats to both human safety and economic development. And as the stories in the preface show, these figurations are very much present in early childhood classrooms.

\section{Bear-Human Entanglements as Subjects of Management and Control}

One of the effects of the frictional figurations of bears as both threats and victims is the perceived imperative to manage their existence and strictly control bear-human encounters. Read together, the bear-child encounters storied in the preface illustrate these frictional figurations. Practices of management and control center on two main purposes: the mitigation of threat and the assurance of future economic gain. One of the preconditions for the effective management and control of animal bodies is the ordering of the animal world. Lugones (2007) argues that global capitalism is contingent upon colonialist classifications of the world's human population into racialized groups. Taking this idea one step further, it is possible to assert that late liberalism is dependent upon neo-colonialist classifications of both human and non-human others on the planet. Beginning during Europe's colonization of most of the globe, and stemming from Darwin's theories of evolution and natural selection, western science has sought to order the animal world (Collard, 2012).

As the two news articles described earlier on in this paper highlight, although bears are constantly classified (through identification, delimitation of their territory and so on), 
bears continually adapt and disrupt the boundaries created by humans, and are therefore often positioned as existing in conflict to humans (see Collard (2012) for a similar argument about cougars). A large amount of resources are dedicated to creating and disseminating information about bears to the public in BC. Many cities' websites in the province list behaviors and measures that humans are expected to adopt in order to avoid such bloody entanglements, stating for instance, "Bears cannot change their behaviour - but we can" (City of Nelson, n.d.). The Bear Aware BC organization is "an educational program designed to prevent and reduce conflicts between people and bears in our communities" (Bear Aware B.C., n.d.). The Bear Aware program uses discourses of protection to bring both the safety of humans, and the survival of bears, under its mandate. Aside from listing recent bear sightings from around the province, the Bear Aware website also houses a number of educational resources, grouped under the heading: Be Bear Aware, Conflict Prevention, Safety, and Education. As evidenced by all of the organization's resources, bears are a powerful constitutive force of both space in BC and the ways in which humans come to perceive their relationship to this space. The Bear Aware encounter in the preface provides a rich example of this. What is important to recall here is that the management and control of bear-human entanglements do not affect both humans and bears equally. Late liberal practices decide which species "will, and should, live and die, and how" (Haraway, 2008 p. 18).

The spaces in which children and bears come together in early childhood classrooms in colonialist BC are contentious, and their relationships are embroiled in complex and evolving dynamics informed by notions of safety and conservation; influenced by sociopolitico-economic forces, and shaped through affective investments (Ahmed, 2004) in fear, love and protection.

\section{Responding to Bear-Child Entanglements}

This paper presented multi-layered stories of bear-child entanglements in early childhood classrooms, as always entangled in past-present social imaginaries. We addressed specifically how such entanglements become and function in late liberal colonialist spaces, as well as how these various bear-child entanglements occur within multiple temporal and spatial layers.

As the reader might already have anticipated, we cannot provide clear answers regarding what to do in practice. In other words, we are not in a position to outline a set of guidelines on how educators should teach children about bears, or nature for that matter. Yet, we are deeply convinced, as Taylor (2013) is, that we are to take these messy entanglements seriously in early childhood education. As 'researchers' and 'practitioners' we are committed to think through what it might entail to respond to the troubles that these 
encounters bring, to acknowledge our own implication in these encounters, and to care for the world we are in-in other words, to stay with the trouble itself. We agree with Metcalf (2008) who writes:

When bears and humans encounter each other, how they encounter each other should not be taken for granted. When bears are encountered as wild on the trail, in legislatures, in environmentalist literature, or ancient mythology, all the tropes of wildness - nuisance, threat, free, untamable, mystical - must be interrogated as the effect of a specific material and conceptual apparatus, not as difference that preexists the encounter and with which we can determinately justify a response. (p. 103)

We therefore end this article by grappling with how we are attempting (partially and imperfectly) to respond to the obligations that animal-child encounters bring.

Because, as we have shown, these entanglements are highly messy and complex, we require situated responses that attend to the specificities of each entanglement. One of the authors, Veronica, has been working with her colleague Affrica Taylor to explore how innovative common world pedagogies (Taylor, 2013) might prepare young children to inherit and co-inhabit messy and complex postcolonial and multispecies worlds ${ }^{\mathrm{ii}}$. In common worlds pedagogies, Taylor (2013) writes, "the pressing question is how to inherit, how to face, the living - and killing - past... in order to be able to move toward multispecies reconciliation" (p. 106). Pacini-Ketchabaw and Taylor (2013) are currently working with educators to explore how classroom practices might place less focus on the boundaries between children and animals, and more focus on the possibilities that reside in the forms of relating and intersecting. Thinking with animals in classrooms might require paying attention to the ways in which nonhumans are typically left out of children's histories and futures. Yet, these common world pedagogies do not assume harmony or balance in the form of a perfect equality in multispecies encounters. Common world pedagogies are an ethico-political project that opens new channels of communication that take into account the messiness already inherent in that communication.

Fikile (one of the authors) is working in the classroom to address messy entanglements by bringing educators' attention and responsiveness to place in ways that bring into view the multiple relationalities, tensions and complexities that are always already entangled prior to and within everyday pedagogical encounters. In her work, Fikile highlights the fluidities, partialities and potential contradictions that emerge in each pedagogical encounter. She is experimenting with forms of responsive, accountable attention that make visible and create interruptions to connections to colonialisms in everyday encounters that might otherwise remain unnoticed. She is working with a 
pedagogy of presencing (Simpson, 2011) through stories that attend to Indigenous relationalities, human-nonhuman entanglements and the ever-present settler colonial tensions that come together in the making of the particular 'natural' places that Fikile encounters with children and educators. Drawing inspiration from Haraway (2008), she is interested in how knowledge-making that foregrounds more-than-human worlds might bring into view multiple stories and create openings towards pedagogies that engage in difficult conversations, disruptive understandings, and different unsettled place relations.

Through storying bear-child figures within the context of $\mathrm{BC}$, we have attempted to show that early childhood education is inextricably entangled with the forces of late liberal colonialism. By making visible some of the endurances and emergences of late liberalism and its coalescence with colonialism in children's concrete and imaginary worlds, we see possibilities for disrupting, interrupting, and confronting these late liberal colonial imaginaries on their slippery territories. By paying close attention to the multiple ways in which mobile late liberal colonialisms endure, re-assemble and mutate within the intensities of everyday encounters in the early childhood classroom, the children, the educators and we can begin the difficult work of responding to the messy worlds we have inherited and live in.

\section{References}

Ahmed, S. (2004). The cultural politics of emotion. New York: Routledge.

Altamirano-Jimenez, I. (2013). Indigenous encoutners with neoliberalism: Place, women, and the environment in Canada and Mexico. Vancouver, BC: UBC Press.

Barcott (2011). Spirit Bear. Retrieved from: http://ngm.nationalgeographic.com/2011/08/kermode-

bear/barcott-text

Bear Aware. (n.d.). Retrieved from: http://www.bearaware.bc.ca/

Bingham, N., Enticott, G., \& Hinchliffe, S. (2008). Biosecurity: Spaces, practices, and boundaries. Environment and Planning A, 40, 1528-1533.

Braun, B. (2002). Colonialism's afterlife: Vision and visuality on the Northwest coast. Cultural Geographies, 9, 202-247.

British Columbia Assembly of First Nations (2012). About BCAFN (British Columbia Assembly of First Nations website). Retrieved from: http://www.bcafn.ca/files/about-bcafn.php

Byrd, J. (2011). The transit of empire: Indigenous critiques of colonialism. Minneapolis, MN: University of Minnesota Press. 
Cameron, E. (2008). Indigenous spectrality and the politics of postcolonial ghost stories. Cultural Geographies, 15, 383-393.

Cameron, E. (2010). Environmental change in the North: Toward different stories. Retrieved from http://niche-canada.org/node/8966

Cameron, E. (2011). Copper stories: Imaginative geographies and material orderings of the Central Canadian Arctic. In A. Baldwin, L. Cameron, and A. Kobayashi (Eds.) Rethinking the great white north: Race, nature and the historical geographies of whiteness in Canada (pp. 169-190). Vancouver: UBC Press.

Cameron, E. (2012). New geographies of story and storytelling. Progress in Human Geography, 36 (5): 572591.

Canadian Broadcasting Corporation (CBC). (2012, September 13). Bear hunting ban declared by 10 B.C. First Nations. CBC News. Retrieved from: http://www.cbc.ca/news/canada/britishcolumbia/story/2012/09/12/bc-natives-seek-bear-hunting-ban.html

Canadian Broadcasting Corporation (CBC). (2013, July 5). Grizzly bear attack of B.C. men brings terror and screams. CBC News. Retrieved from: http://www.cbc.ca/news/canada/britishcolumbia/story/2013/07/04/bc-fernie-grizzly-bear-attack.html

City of Coquitlam. (n.d.). Bear aware Coquitlam. Retrieved from: http://www.coquitlam.ca/publicsafety/animal-pest-control/bear-aware-coquitlam.aspx

City of Nelson. (n.d.). Bear awareness. Retrieved from: http://www.nelson.ca/EN/main/services/animalbylaw-services/bear-aware.html

Canadian Television Network (CTV). (2013, July 12). Man nursing scratches after Mission black bear attack. CTV News. Retrieved from: http://bc.ctvnews.ca/man-nursing-scratches-after-mission-black-bearattack-1.1364420

Coats, L. (2013, March 21). Lucy Coats's top 10 bear picture books. The Guardian. Retrieved from: http://www.guardian.co.uk/childrens-books-site/2013/mar/21/lucy-coats-top-10-bear-picture-books

Collard, R-C. (2012). Cougar figures, gender, and the performances of predation. Gender, Place \& Culture: A Journal of Feminist Geography, 19(4), 518-540.

de la Cadena, M. (2010). Indigenous cosmopolitics in the Andes: Conceptual reflections beyond 'politics'. Cultural Anthropology, 25(2), 334-370.

Dempsey, J. (2010). Tracking grizzly bears in British Columbia's environmental politics. Environment and planning, 42, 1138-1156.

di Tomasso, L. (2012). Engaging with early childhood educators' encounters with race: An exploration of the discursive, material and affective dimensions of whiteness and processes of racialization (Unpublished Masters dissertation). University of Victoria, Victoria, B.C.

First Nations Drum. (2012, July 29). Coastal First Nations declare ban on trophy bear hunting. Retrieved from: http://www.firstnationsdrum.com/2012/11/coastal-first-nations-declare-ban-on-trophy-bearhunting/ 
First Peoples' Heritage, Language and Culture Council (2012). Language (First Peoples' Heritage, Language and Culture Council webpage on language). Retrieved from: http://www.fphlcc.ca/language

Government of British Columbia. (2001). Black bears in British Columbia: Ecology, conservation and management. Retrieved from http://www.env.gov.bc.ca/wld/documents/blackbear.pdf

Haraway, D. (1995). Otherwordly conversations, terran topics, local terms. In V. Shiva \& N. Moser (Eds.), Biopolitics: A feminist and ecological reader on biotechnology (pp. 69-92). London, UK: Palgrave Macmillan.

Haraway, D. (1997).Modest_witness@Second_Millennium.FemaleMan@_Meets_Onco Mouse ${ }^{\mathrm{TM}}$ : feminism and technoscience. New York: Routledge.

Haraway, D. (2008). When species meet. Minneapolis, MN: University of Minnesota Press.

Haraway, D. (2012). Awash in urine: DES and Premarin ${ }^{\circledR}$ in multispecies response-ability. WSQ: Women's Studies Quarterly 40(1 \& 2), 301-316.

Harrington, J., \& Arnott, M. (2013). Spirit Bear. Retrieved from: http://ecobooks4kids.wordpress.com/spiritbear-childrens-book/

Hemmings, R. (2007). A taste of nostalgia: Children's books from the golden age-Carroll, Grahame, and Milne. Children's Literature, 35, 54-79.

Kutzer, M. D. (2000). Empire's children: Empire and imperialism in classic British children's books. New York: Garland.

Lugones, M. (2007). Heterosexualism and the colonial / modern gender system. Hypatia, 22(1), 186-209.

Mbembe, A. (2001). On the postcolony: Studies on the history of society and culture. Berkeley: University of California Press.

Milne, A. A. (1926). Winnie-the-Pooh. London, UK: Methuen.

Metcalf, J. (2008). Intimacy without proximity: Encountering grizzlies as a companion species. Environmental Philosophy, 5(2), 99-128.

Nxumalo, F., Pacini-Ketchabaw, V., \& Rowan, C. (2011). Lunch time at the child care centre: Neoliberal assemblages in early childhood education. Journal of Pedagogy, 2(2), 195-223.

Pacini-Ketchabaw, V., Nxumalo, F., \& Rowan, C. (in press). Researching neoliberal and neocolonial assemblages in early childhood education. International Review of Qualitative Reasearch.

Pacini-Ketchabaw, V., Nxumalo, F., Kocher, L, Elliot, E., \& Sanchez, A. (forthcoming) Journeys: Complexifying early childhood practices through pedagogical narration. Toronto, ON, Canada: University of Toronto Press.

Pacini-Ketchabaw, V., \& Taylor, A. (2013, June). Learning to inherit and respond to the challenges of the Anthropocene: Toward an early years multispecies pedagogy. Paper presented at the "7th World Environmental Education Congress", Marrakech, Morocco.

Povinelli, E.A. (2011). Economies of abandonment: Social belonging and endurance in late liberalism. Durham: Duke University Press. 
Povinelli, E. (2012, November). Geontologies: Indigenous Transmedia in the Anthropocene. Public lecture, John E. Sawyer Seminar on the Comparative Study of Cultures. Indigenous cosmopolitics: Dialogues about the reconstitution of worlds, delivered at University of California Davis. Retrieved from: http://webcast.ucdavis.edu/llnd/2f1933c

Povinelli, E. A. (2013, January). Geontologies: A Requiem to Late Liberalism. Keynote lecture, Haus de Kulturen der Welt Anthropocene Project, delivered at Humboldt-Universität, Berlin, Germany. Retrieved from:

http://www.hkw.de/en/programm/2013/anthropozaen/multimedia_anthropozaen/video_anthropozaen/vi deo_anthropozaen.php

Rosen, M. \& Oxenbury, H. (2003). We're Going on a Bear Hunt. New York: Margaret K. McElderry Books.

Tims, A. (2012, November 5). How we made: Helen Oxenbury and Michael Rosen on 'We're Going on a Bear Hunt'. The Guardian. Retrieved from: http://www.guardian.co.uk/books/2012/nov/05/how-we-madebear-hunt

Simpson, L. (2011). Dancing on our turtle's back: Stories of Nishnaabeg re-creation, resurgence, and a new emergence. Winnipeg: Arbeiter Ring Publishers.

Taylor, A., Blaise, M., \& Giugni, M. (2013). Haraway's 'bag lady story-telling': Relocating childhood and learning within a 'post-human landscape'. Discourse: Studies in the Cultural Politics of Education, 34(1), 48-62.

Taylor, A. (2013). Reconfiguring the Natures and Cultures of Childhood. London: Taylor \& Francis.

Timeto, F. (2011). Diffracting the rays of technoscience: A situated critique of representation. Poiesis and Praxis, 8(2-3), 151-167.

Tsing, A. (2005). Friction: an ethnography of global connection. Princeton, NJ: Princeton University Press.

Winnie. (n.d.). Historica Minutes, The Historica Foundation of Canada. Retrieved from: https://www.historicadominion.ca/content/heritage-minutes/winnie

\section{Endnotes}

\footnotetext{
'We use both 'bear-human' and 'bear-child' entanglements. When we refer to bear-human, we include children. Bear-child is used when we are referring specifically to encounters between children and bears. At times we also refer to 'bear-child/human' to combine both bear-human and bear-child.

ii See http://commonworlds.net
} 


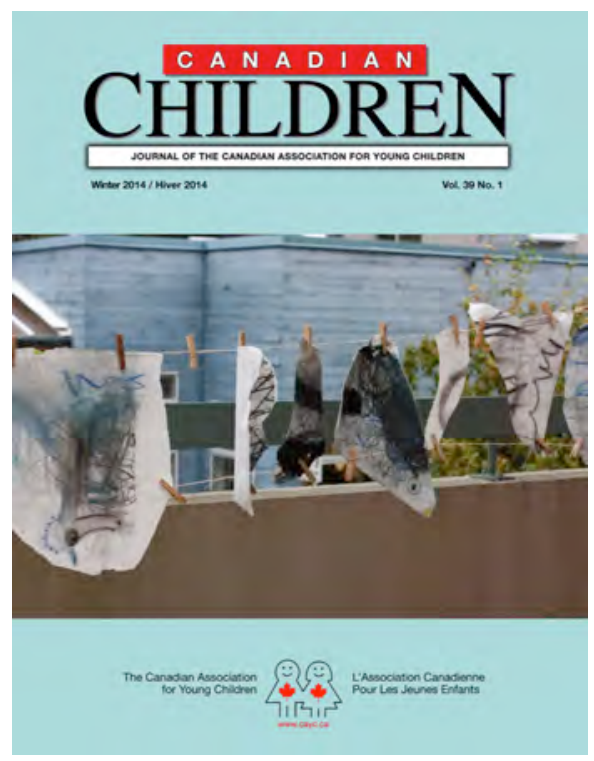

\section{In this issue:}

From the Editor's Desk

Special Issue: Neoliberalism

Guest Editor Dr. Luigi Iannacci, PhD, Trent University,

Peterborough, Ontario

I've got my EYE on you:

Schooled Readiness, Standardized Testing, and Developmental Surveillance

by Emily Ashton

Bear-Child Stories in Late Liberal Colonialist Spaces of Childhood by Veronica Pacini-Ketchabaw, Lara di Tomasso, Fikile Nxumalo

Producing Neoliberal Parenting Subjectivities:

ANT-Inspired Readings from an Informal Early Learning Program by Rosamund Stooke

Neoliberal Fun and Happiness in Early Childhood Education by Cristina D. Vintimilla

Radical Education and the Common School:

A Democratic Alternative

by Michael Fielding and Peter Moss

Reviewed by Kim Atkinson

Call for Contributions:

'The Visual Arts in Early Childhood Education'

Find other articles from this issue at www.cayc.ca 